Article

\title{
The Effect of Fines on Hydraulic Conductivity of Lawrencepur, Chenab and Ravi Sand
}

\author{
Tanveer Ahmed Khan ${ }^{1, * \mathbb{D}}$, Khalid Farooq ${ }^{2}$, Mirza Muhammad ${ }^{3}$, Mudasser Muneer Khan ${ }^{1}$, \\ Syyed Adnan Raheel Shah ${ }^{4, *}$, Muhammad Shoaib ${ }^{5}$, Muhammad Asif Aslam ${ }^{1}$ and \\ Syed Safdar Raza ${ }^{1}$ \\ 1 University College of Engineering \& Technology, Bahauddin Zakariya University, Multan 60000, Pakistan; \\ mudasserkhan@bzu.edu.pk (M.M.K.); masifaslam@bzu.edu.pk (M.A.A.); safdarshah91@yahoo.com (S.S.R.) \\ 2 Department of Civil Engineering, University of Engineering \& Technology, Lahore 54700, Pakistan; \\ kfch@uet.edu.pk \\ 3 National Engineering Services (NESPAK), Lahore 54700, Pakistan; mirza_muhammad@yahoo.com \\ 4 Department of Civil Engineering, Pakistan Institute of Engineering and Technology, Multan 60000, Pakistan \\ 5 Department of Agricultural Engineering, Bahauddin Zakariya University, Multan 60000, Pakistan; \\ muhammadshoaib@bzu.edu.pk \\ * Correspondence: tanveerkhan@bzu.edu.pk (T.A.K.); syyed.adnanraheelshah@uhasselt.be (S.A.R.S.); \\ Tel.: +92-333-880-4950 (T.A.K.)
}

Received: 6 July 2019; Accepted: 12 October 2019; Published: 2 November 2019

\begin{abstract}
The amount of fines in sand greatly influence the permeability of sandy soils. Thus, this research was conducted to study the effect of plastic and non-plastic fines on the permeability of three types of sands (Lawrencepur sand, Chenab sand and Ravi sand). For this purpose, plastic and non-plastic fines were collected from different location of Lahore. Samples were prepared by mixing plastic and non-plastic fines into each type of sand separately, in amounts ranging from $0 \%$ to $50 \%$ with increments of five percent. Overall 63 samples were prepared. Sieve analysis and hydrometric analysis were performed to obtain particle size distribution for each sample. Atterberg's limits were also determined and each sample was classified according to the Unified Soil Classification System (USCS). Compaction tests were performed on all samples as per the procedure in a standard Proctor test. The test samples were compacted in permeability molds with optimum moisture contents to obtain the density, as per a standard Proctor test. Hydraulic conductivity tests were performed on all sixty-three samples using a constant head permeameter and a falling head permeameter. Permeability results were plotted against the percentage of fines added. It was noted from the curves that the permeability of sand-fine mixtures shows a decreasing trend with the addition of fine contents. A few trials were performed to formulate a correlation. Validation of the correlation was performed with the results of 52 data sets from the field. Finally, the devised correlation was compared with three empirical equations proposed by Mujtaba, Kozeny-Carman and Hazen.
\end{abstract}

Keywords: fluid; soil; permeability; sand; fines; transport

\section{Introduction}

Permeability is an important physical property of soil whose understanding is essential in settlement, seepage and stability analyses $[1,2]$. The stability of structures depends to a large degree on the interaction of the said soil with water, or in other words, the ability of water to flow through the soil [3,4]. Moreover, in-depth understanding of soil permeability is needed to estimate the quantity of seepage under and through dams, levees and embankments etc. It also helps to plan dewatering methods to facilitate underground construction [5]. Furthermore, many dam failures have occurred due to insufficient geotechnical and geological investigations. The failure due to seepage through a dam body and/or foundation accounts for almost $30 \%$ of total failures [6]. 
While studying the soil properties, D represents the diameter of particles, and D50 means a cumulative $50 \%$ point of diameter (or $50 \%$ pass particle size); D10 means a cumulative $10 \%$ point of diameter. Numerous relationships between the permeability and grain size distribution indices (like uniformity coefficient, coefficient of gradation, median grain size (D50) and effective grain size (D10)) of the soil have been reported, such as those in Hazen [7], Zunker [8], Carman [9], Burmister [10], Michaels and Lin [11], Olsen [12], Mitchell et al. [13] and Wang and Huang [14]. Lately, Alyamani and Sen [15], Koltermann and Gorelick [16], D'Andrea and Boadu [17], Chapuis [18], Sinha and Wang [19] and Cote et al. [20] established different models to corelate the hydraulic conductivity of soils with their index properties. The hydraulic conductivity has been discussed with sand as well [21], focusing on grain size of soils [22]. However, equations based on grain size distribution do not yield good results for clayey soils and soils with effective grain sizes greater than $3 \mathrm{~mm}$ [23]. The presence of grains of extreme-size also produces inaccurate predictions of soil permeability. The prediction of permeability of well-graded soils is particularly difficult due to the void-filling trend of various-sized particles [24]. On the other hand, laboratory and field tests have their limitations and weaknesses, such as the variation of permeability in horizontal and vertical directions in soils [25]; disturbances in extracted samples and how closely they represent field conditions [26,27]; and costly and time-consuming field pumping tests [27].

Silica fume was used to improve the qualities of clay used as clay liners. It was observed that it reduced the plasticity index (from $\mathrm{CH}$ to $\mathrm{CL}$ ), permeability and swelling pressure considerably and increased the compressive strength [28]. Two types of silts, fine sands and coarse sands were mixed with varying amounts of commercial bentonite, and hydraulic conductivity was determined with a consolidometer permeameter. It was found that when bentonite was mixed with coarser material, the hydraulic conductivity (log) changed linearly with void ratio [1]. The permeability of dune sand was greatly affected and reduced to $10^{-8} \mathrm{~cm} / \mathrm{s}$ from $10^{-4} \mathrm{~cm} / \mathrm{s}$ with the addition of $10 \%$ bentonite [29].

Shear strength and permeability are two important characteristics desirable for almost all geotechnical projects. In many cases, these two are required concurrently, meaning these should be attained at maximum dry density (MDD) and optimum moisture content (OMC) of soil. As laboratory tests for determining permeability and shear strength are time-consuming, it is desirable to devise models to predict compacted soil's permeability based on the index properties of soils. Efforts have been made to relate these important parameters with the indices of soils, such as grain size distribution and plasticity characteristics [5].

Pakistan is a vast country having large plains. Rivers (Indus, Chenab, Jhelum, Ravi, Bias and Sutlej) along with other tributaries pass through these plains. Sands of different gradations are encountered in these rivers and are widely used in construction works. The areas near the rivers are regularly subjected to the erosive action of river flow, especially during flood seasons, also causing damage to the river training works along the rivers and other infrastructure. In most cases, a need arises to modify the properties of riverbed materials by mixing these with other, locally available, cheaper materials. In this context, the predicted permeability (hydraulic conductivity) values of these sands mixed with different proportions of fines will be very helpful. Thus, in this research sand samples from Chenab, Lawrencepur and Ravi rivers were used. The two fines (plastic and non-plastic) were added to each type of the sand separately to prepare representative samples on MDD and OMC determined through the standard Proctor test, and permeability tests were executed. The results were analyzed, and a correlation was developed to predict permeability values from the given parameters. Finally, the correlation developed was compared with three other permeability correlations.

\section{Materials and Methods}

Three types of sands (quartz as main mineral) were collected from Chenab, Lawrencepur and Ravi rivers. These are the main and the most common type of fine aggregates used in various civil engineering projects in Pakistan [30]. Plastic and non-plastic fines are predominantly clays and silts respectively, and were collected from different localities of Lahore, Pakistan. Chenab, Lawrencepur 
and Ravi sands are designated as CS, LS and RS respectively, in the following discussion. Furthermore, PF represents plastic fines and NPF represents non-plastic fines. PF were collected from near Expo Centre Lahore, whereas NPF from the Habanspura area of Lahore.

All sands and fine samples were separated from vegetation, clods and other materials of larger sizes. Larger sizes in PF and NPF were broken into small fractions. All materials were then passed through sieve number 4 . Each PF and NPF were added separately to each type of sand, ranging from $0 \%$ to $50 \%$ of the total weight of sample. Overall 63 samples were prepared and following tests were performed in the laboratory:

(a) Grain size analysis (ASTM D-422);

(b) Standard Proctor test (ASTM D-422);

(c) Atterberg limits (ASTM D-4318);

(d) Constant head permeability test (ASTM-D 2434);

(e) Falling head permeability test.

\section{Results and Discussion}

\subsection{Grain Size Analysis}

The gradation curves of CS, LS and RS are given in Figure 1, along with curves of NPF and PF. The LS was well graded when compared to CS and RS, whereas RS was the most uniformly graded and CS lies somewhere between the two. Understandably, the curve of PF is on the finer side of the curve of NPF. Gradation curves were drawn for all 63 samples and observations were made to calculate the uniformity coefficient $\left(\mathrm{C}_{\mathrm{u}}\right)$ and coefficient of gradation $\left(\mathrm{C}_{\mathrm{c}}\right)$. Consistency limits (liquid limit and plastic limit) were determined for the soil samples attaining some plasticity due to the addition of fines. All samples were then classified according to Unified Soil Classification System (USCS). The median grain size ( $\mathrm{D}_{50}$, diameter corresponding to $50 \%$ finer) varied between 0.01 and $0.9 \mathrm{~mm}$, whereas the effective grain size $\left(D_{10}\right)$ varied from 0.005 to $0.33 \mathrm{~mm}$. The gradation of all samples is not shown here due to a very large number of curves, though the observations from the gradation curves, consistency limits and soil symbols of all the samples are listed in Table 1.

Most samples were non-plastic (NP) except some with higher percentages of plastic fines. It is also noted that most of the samples were silty sand (SM). As per USCS, both LS and CS were poorly graded sand (SP) while RS was poorly graded sand with silt (SP-SM).

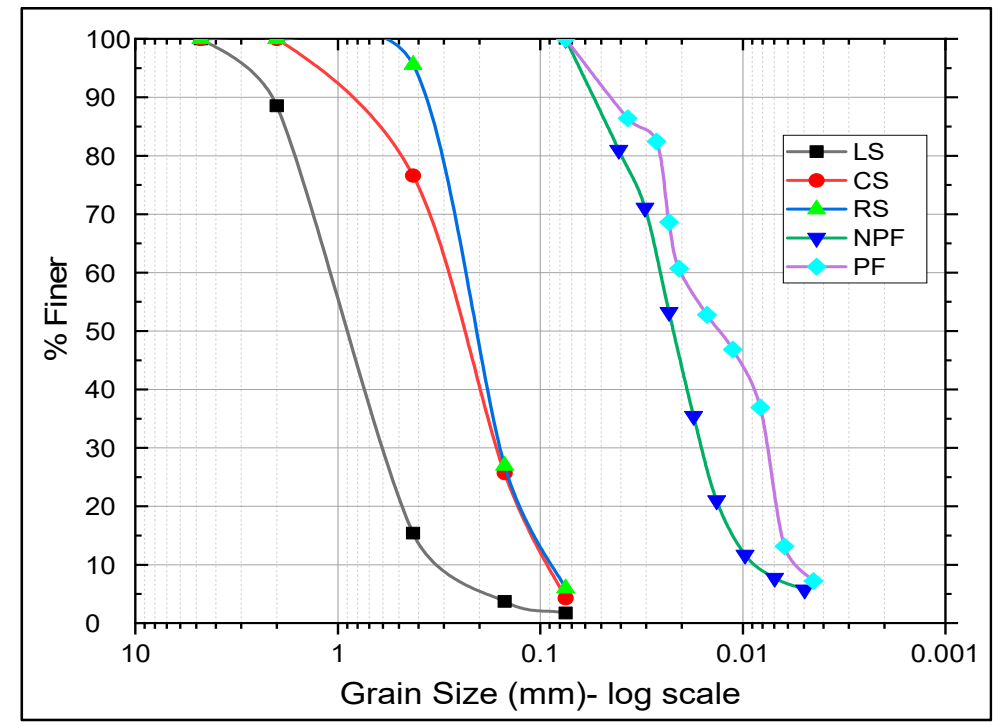

Figure 1. The gradation curves of three types of sands and two fines. 
Table 1. Data from gradation curves, consistency limits and soil symbols of all the samples.

\begin{tabular}{|c|c|c|c|c|c|c|c|c|c|c|c|c|c|}
\hline $\begin{array}{c}\text { Sample } \\
\text { No }\end{array}$ & $\begin{array}{l}\text { Sand } \\
\text { Type }\end{array}$ & $\begin{array}{l}\text { FINES } \\
\text { TYPE }\end{array}$ & $\begin{array}{c}\text { Fines } \\
(\%)\end{array}$ & $\begin{array}{c}D_{10} \\
(\mathrm{~mm})\end{array}$ & $\begin{array}{c}D_{30} \\
(\mathrm{~mm})\end{array}$ & $\begin{array}{c}D_{60} \\
(\mathrm{~mm})\end{array}$ & $\begin{array}{c}D_{50} \\
(\mathrm{~mm})\end{array}$ & $\mathrm{C}_{\mathbf{u}}$ & $\mathrm{C}_{\mathrm{c}}$ & $\begin{array}{l}\text { Liquid } \\
\text { Limit }\end{array}$ & $\begin{array}{c}\text { Plastic } \\
\text { Limit }\end{array}$ & $\begin{array}{l}\text { Plasticity } \\
\text { Index }\end{array}$ & $\begin{array}{c}\text { Soil } \\
\text { Classification }\end{array}$ \\
\hline 1 & CS & - & - & 0.09 & 0.16 & 0.31 & 0.25 & 3.44 & 0.92 & - & - & $\mathrm{NP}$ & SP \\
\hline 2 & CS & NPF & 5 & 0.076 & 0.16 & 0.28 & 0.25 & 3.68 & 1.20 & - & - & $\mathrm{NP}$ & SP-SM \\
\hline 3 & CS & NPF & 10 & 0.055 & 0.15 & 0.28 & 0.23 & 5.09 & 1.46 & - & - & $\mathrm{NP}$ & $\mathrm{SM}$ \\
\hline 4 & CS & $\mathrm{NPF}$ & 15 & 0.043 & 0.13 & 0.27 & 0.21 & 6.28 & 1.46 & - & - & $\mathrm{NP}$ & SM \\
\hline 5 & CS & NPF & 20 & 0.025 & 0.098 & 0.22 & 0.16 & 8.80 & 1.75 & - & - & $\mathrm{NP}$ & SM \\
\hline 6 & CS & NPF & 25 & 0.026 & 0.081 & 0.23 & 0.18 & 8.85 & 1.10 & - & - & NP & SM \\
\hline 7 & CS & NPF & 30 & 0.024 & 0.067 & 0.22 & 0.17 & 9.17 & 0.85 & - & - & NP & SM \\
\hline 8 & CS & NPF & 35 & 0.016 & 0.05 & 0.19 & 0.14 & 11.88 & 0.82 & - & - & NP & $\mathrm{SM}$ \\
\hline 9 & CS & NPF & 40 & 0.015 & 0.042 & 0.18 & 0.12 & 12.00 & 0.65 & 16.85 & - & $\mathrm{NP}$ & SM \\
\hline 10 & CS & NPF & 45 & 0.013 & 0.033 & 0.17 & 0.077 & 13.08 & 0.49 & 18.25 & - & $\mathrm{NP}$ & $\mathrm{SM}$ \\
\hline 11 & CS & NPF & 50 & 0.013 & 0.028 & 0.14 & 0.067 & 10.77 & 0.43 & 19.30 & - & $\mathrm{NP}$ & ML \\
\hline 12 & CS & PF & 5 & 0.053 & 0.16 & 0.28 & 0.24 & 5.28 & 1.73 & - & - & $\mathrm{NP}$ & SP-SM \\
\hline 13 & CS & PF & 10 & 0.051 & 0.14 & 0.28 & 0.22 & 5.49 & 1.37 & - & - & $\mathrm{NP}$ & $\mathrm{SM}$ \\
\hline 14 & CS & $\mathrm{PF}$ & 15 & 0.03 & 0.13 & 0.26 & 0.22 & 8.67 & 2.17 & - & - & NP & SM \\
\hline 15 & CS & $\mathrm{PF}$ & 20 & 0.018 & 0.098 & 0.26 & 0.18 & 14.44 & 2.05 & - & - & NP & SM \\
\hline 16 & CS & PF & 25 & 0.017 & 0.077 & 0.23 & 0.17 & 13.53 & 1.52 & - & - & $\mathrm{NP}$ & $\mathrm{SM}$ \\
\hline 17 & CS & PF & 30 & 0.013 & 0.055 & 0.22 & 0.17 & 16.92 & 1.06 & - & - & $\mathrm{NP}$ & SM \\
\hline 18 & CS & PF & 35 & 0.012 & 0.039 & 0.19 & 0.14 & 15.83 & 0.67 & - & - & $\mathrm{NP}$ & $\mathrm{SM}$ \\
\hline 19 & CS & PF & 40 & 0.0094 & 0.03 & 0.18 & 0.13 & 19.15 & 0.53 & 18.80 & - & $\mathrm{NP}$ & $\mathrm{SM}$ \\
\hline 20 & CS & PF & 45 & 0.0085 & 0.027 & 0.17 & 0.087 & 20.00 & 0.50 & 19.75 & 18.14 & 1.61 & $\mathrm{SM}$ \\
\hline 21 & CS & PF & 50 & 0.0078 & 0.023 & 0.14 & 0.058 & 17.95 & 0.48 & 20.25 & 17.97 & 2.28 & ML \\
\hline 22 & LS & - & - & 0.26 & 0.57 & 1.2 & 0.87 & 4.62 & 1.04 & - & - & $\mathrm{NP}$ & SP \\
\hline 23 & LS & NPF & 5 & 0.17 & 0.54 & 1.1 & 0.86 & 6.47 & 1.56 & - & - & $\mathrm{NP}$ & SP-SM \\
\hline 24 & LS & NPF & 10 & 0.06 & 0.49 & 1 & 0.78 & 16.67 & 4.00 & - & - & $\mathrm{NP}$ & $\mathrm{SM}$ \\
\hline 25 & LS & NPF & 15 & 0.046 & 0.45 & 0.94 & 0.74 & 20.43 & 4.68 & - & - & $\mathrm{NP}$ & SM \\
\hline 26 & LS & NPF & 20 & 0.039 & 0.41 & 0.9 & 0.7 & 23.08 & 4.79 & - & - & $\mathrm{NP}$ & $\mathrm{SM}$ \\
\hline 27 & LS & $\mathrm{NPF}$ & 25 & 0.029 & 0.26 & 0.87 & 0.67 & 30.00 & 2.68 & - & - & $\mathrm{NP}$ & $\mathrm{SM}$ \\
\hline 28 & LS & NPF & 30 & 0.026 & 0.17 & 0.8 & 0.6 & 30.77 & 1.39 & 14.30 & - & $\mathrm{NP}$ & $\mathrm{SM}$ \\
\hline 29 & LS & NPF & 35 & 0.016 & 0.066 & 0.7 & 0.51 & 43.75 & 0.39 & 15.40 & - & NP & SM \\
\hline 30 & LS & NPF & 40 & 0.015 & 0.041 & 0.6 & 0.41 & 40.00 & 0.19 & 16.70 & - & NP & SM \\
\hline 31 & LS & NPF & 45 & 0.014 & 0.028 & 0.51 & 0.17 & 36.43 & 0.11 & 18.72 & - & NP & SM \\
\hline 32 & LS & NPF & 50 & 0.013 & 0.028 & 0.45 & 0.07 & 34.62 & 0.13 & 19.80 & - & $\mathrm{NP}$ & ML \\
\hline 33 & LS & $\mathrm{PF}$ & 5 & 0.18 & 0.55 & 1.1 & 0.84 & 6.11 & 1.53 & - & - & $\mathrm{NP}$ & SP-SM \\
\hline
\end{tabular}


Table 1. Cont

\begin{tabular}{|c|c|c|c|c|c|c|c|c|c|c|c|c|c|}
\hline $\begin{array}{c}\text { Sample } \\
\text { No }\end{array}$ & $\begin{array}{l}\text { Sand } \\
\text { Type }\end{array}$ & $\begin{array}{l}\text { FINES } \\
\text { TYPE }\end{array}$ & $\begin{array}{c}\text { Fines } \\
(\%)\end{array}$ & $\begin{array}{c}D_{10} \\
(\mathrm{~mm})\end{array}$ & $\begin{array}{c}D_{30} \\
(\mathrm{~mm})\end{array}$ & $\begin{array}{c}D_{60} \\
(\mathrm{~mm})\end{array}$ & $\begin{array}{c}D_{50} \\
(\mathrm{~mm})\end{array}$ & $\mathrm{C}_{\mathbf{u}}$ & $\mathrm{C}_{\mathrm{c}}$ & $\begin{array}{l}\text { Liquid } \\
\text { Limit }\end{array}$ & $\begin{array}{c}\text { Plastic } \\
\text { Limit }\end{array}$ & $\begin{array}{l}\text { Plasticity } \\
\text { Index }\end{array}$ & $\begin{array}{c}\text { Soil } \\
\text { Classification }\end{array}$ \\
\hline 34 & LS & PF & 10 & 0.07 & 0.49 & 1 & 0.77 & 14.29 & 3.43 & - & - & $\mathrm{NP}$ & SM \\
\hline 35 & LS & PF & 15 & 0.032 & 0.45 & 0.94 & 0.73 & 29.38 & 6.73 & - & - & $\mathrm{NP}$ & $\mathrm{SM}$ \\
\hline 36 & LS & PF & 20 & 0.023 & 0.4 & 0.9 & 0.7 & 39.13 & 7.73 & - & - & $\mathrm{NP}$ & SM \\
\hline 37 & LS & PF & 25 & 0.019 & 0.26 & 0.87 & 0.66 & 45.79 & 4.09 & 16.80 & 16.17 & 0.63 & SM \\
\hline 38 & LS & PF & 30 & 0.016 & 0.17 & 0.8 & 0.6 & 50.00 & 2.26 & 17.85 & 16.87 & 0.98 & SM \\
\hline 39 & LS & $\mathrm{PF}$ & 35 & 0.013 & 0.05 & 0.7 & 0.5 & 53.85 & 0.27 & 19.60 & 17.88 & 1.72 & SM \\
\hline 40 & LS & PF & 40 & 0.01 & 0.034 & 0.62 & 0.42 & 62.00 & 0.19 & 20.30 & 17.84 & 2.46 & SM \\
\hline 41 & LS & PF & 45 & 0.0092 & 0.028 & 0.52 & 0.18 & 56.52 & 0.16 & 22.77 & 19.57 & 3.20 & $\mathrm{SM}$ \\
\hline 42 & LS & PF & 50 & 0.0085 & 0.024 & 0.46 & 0.068 & 54.12 & 0.15 & 23.20 & 20.03 & 3.17 & ML \\
\hline 43 & RS & - & - & 0.085 & 0.17 & 0.26 & 0.22 & 3.06 & 1.31 & - & - & $\mathrm{NP}$ & SP-SM \\
\hline 44 & RS & NPF & 5 & 0.066 & 0.16 & 0.26 & 0.21 & 3.94 & 1.49 & - & - & $\mathrm{NP}$ & SP-SM \\
\hline 45 & RS & NPF & 10 & 0.036 & 0.14 & 0.24 & 0.19 & 6.67 & 2.27 & - & - & $\mathrm{NP}$ & $\mathrm{SM}$ \\
\hline 46 & RS & NPF & 15 & 0.027 & 0.13 & 0.23 & 0.18 & 8.52 & 2.72 & - & - & $\mathrm{NP}$ & $\mathrm{SM}$ \\
\hline 47 & RS & NPF & 20 & 0.017 & 0.09 & 0.22 & 0.18 & 12.94 & 2.17 & - & - & NP & SM \\
\hline 48 & RS & NPF & 25 & 0.017 & 0.075 & 0.2 & 0.17 & 11.76 & 1.65 & - & - & NP & SM \\
\hline 49 & RS & NPF & 30 & 0.014 & 0.05 & 0.19 & 0.16 & 13.57 & 0.94 & - & - & $\mathrm{NP}$ & $\mathrm{SM}$ \\
\hline 50 & RS & NPF & 35 & 0.013 & 0.038 & 0.18 & 0.15 & 13.85 & 0.62 & - & - & $\mathrm{NP}$ & SM \\
\hline 51 & RS & NPF & 40 & 0.013 & 0.031 & 0.017 & 0.11 & 1.31 & 4.35 & 17.70 & - & $\mathrm{NP}$ & SM \\
\hline 52 & RS & $\mathrm{NPF}$ & 45 & 0.013 & 0.029 & 0.16 & 0.084 & 12.31 & 0.40 & 18.90 & - & $\mathrm{NP}$ & $\mathrm{SM}$ \\
\hline 53 & RS & NPF & 50 & 0.013 & 0.021 & 0.14 & 0.048 & 10.77 & 0.24 & 19.70 & - & $\mathrm{NP}$ & ML \\
\hline 54 & RS & PF & 5 & 0.066 & 0.16 & 0.24 & 0.2 & 3.64 & 1.62 & - & - & $\mathrm{NP}$ & SP-SM \\
\hline 55 & RS & $\mathrm{PF}$ & 10 & 0.03 & 0.12 & 0.24 & 0.19 & 8.00 & 2.00 & - & - & NP & SM \\
\hline 56 & RS & $\mathrm{PF}$ & 15 & 0.021 & 0.14 & 0.23 & 0.18 & 10.95 & 4.06 & - & - & NP & SM \\
\hline 57 & RS & PF & 20 & 0.014 & 0.09 & 0.22 & 0.18 & 15.71 & 2.63 & - & - & $\mathrm{NP}$ & $\mathrm{SM}$ \\
\hline 58 & RS & PF & 25 & 0.013 & 0.075 & 0.2 & 0.17 & 15.38 & 2.16 & - & - & $\mathrm{NP}$ & SM \\
\hline 59 & RS & PF & 30 & 0.011 & 0.047 & 0.18 & 0.16 & 16.36 & 1.12 & - & - & $\mathrm{NP}$ & $\mathrm{SM}$ \\
\hline 60 & RS & PF & 35 & 0.0084 & 0.032 & 0.18 & 0.15 & 21.43 & 0.68 & - & - & $\mathrm{NP}$ & $\mathrm{SM}$ \\
\hline 61 & RS & PF & 40 & 0.0088 & 0.028 & 0.17 & 0.12 & 19.32 & 0.52 & 17.90 & - & $\mathrm{NP}$ & SM \\
\hline 62 & RS & PF & 45 & 0.0083 & 0.025 & 0.16 & 0.084 & 19.28 & 0.47 & 19.50 & 18.32 & 1.18 & SM \\
\hline 63 & RS & $\mathrm{PF}$ & 50 & 0.0063 & 0.019 & 0.13 & 0.045 & 20.63 & 0.44 & 20.10 & 17.94 & 2.16 & ML \\
\hline
\end{tabular}




\subsection{Compaction Tests}

Standard Proctor tests were performed on all 63 samples in accordance with the guidelines of ASTM D-698. The lowest value of MDD $\left(1.6 \mathrm{~g} / \mathrm{cm}^{3}\right)$ was observed for Ravi sand. This was obvious, as RS was the most uniformly graded soil (mentioned earlier). The highest MDD was for Lawrencepur sand mixed with 20\% non-plastic fines (LS20NPF). Figure 2 shows the compaction curves of the lowest dry density (RS), highest dry density (LS20NPF), CS and LS soil samples.

The variations in MDD and OMC with the addition of two fines are shown in Figures 3 and 4 respectively. For LS mixed with both fines, MDD increased up to $20 \%$ fine content and then started to decrease, whereas, for both CS and RS, MDD increased for up to $35 \%$ fine content and then either remained the same or decreased a small amount. The initial increase in MDD may be attributable to the occupation of voids in sand by the fines. The decline in density after reaching the peak may be due to the bouncing of particles, thereby increasing the space within particles and reducing dry density.

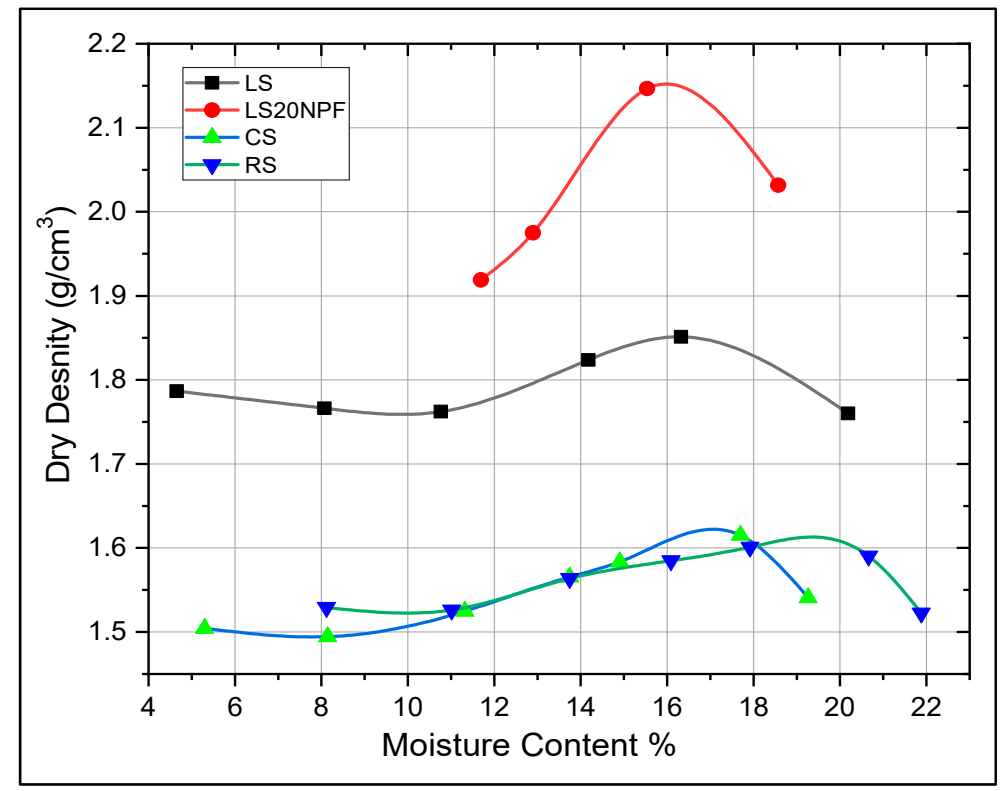

Figure 2. Standard Proctor test results.

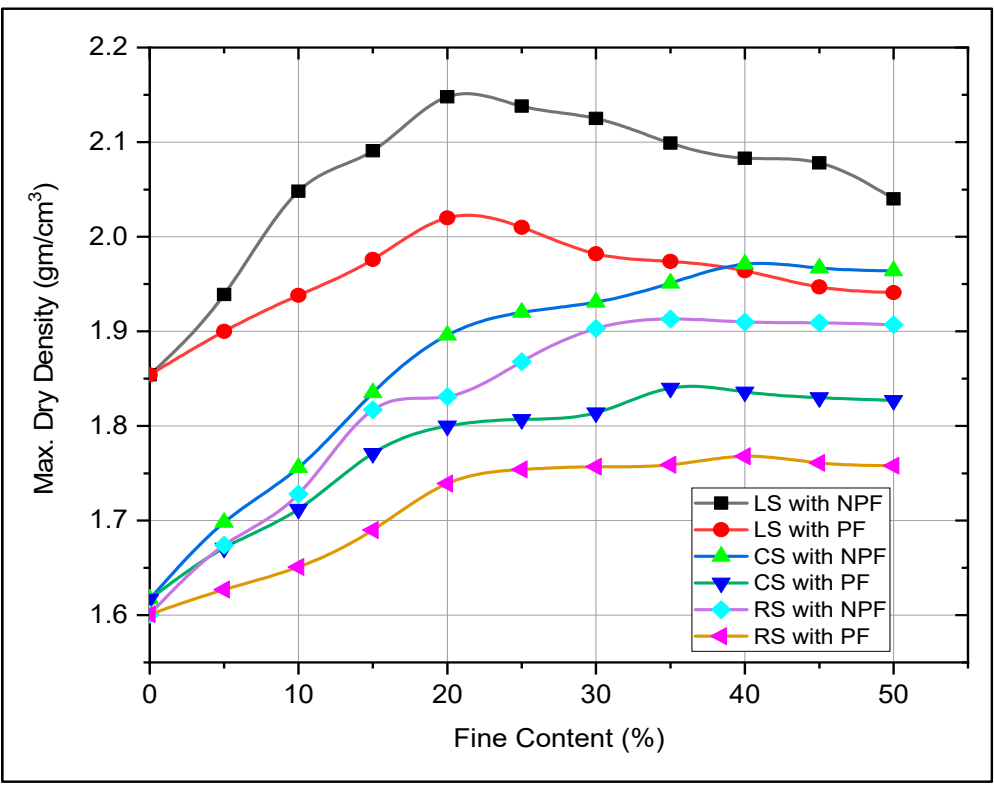

Figure 3. Variation in maximum dry density with different fine contents. 


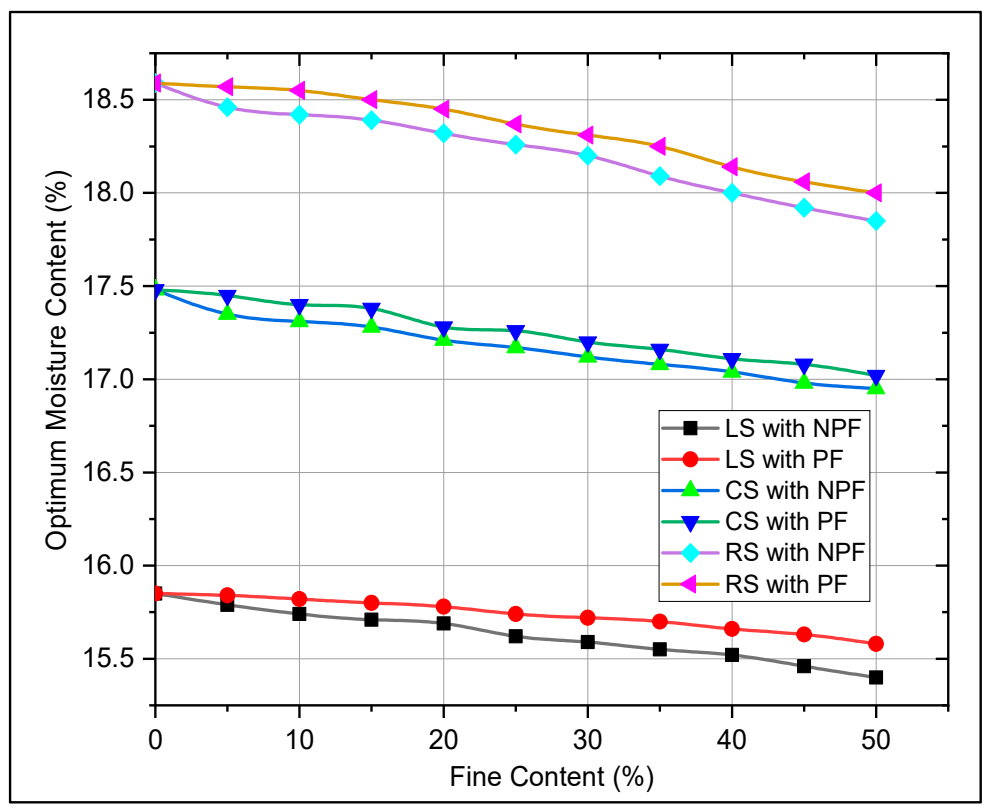

Figure 4. Variation in optimum moisture content with different fine contents.

\subsection{Permeability}

Constant head permeability tests were performed in accordance with the guidelines of ASTM D-2434 on LS mixed with up to $25 \%$ and $20 \%$ of NPF and PF respectively. The same test was conducted on CS and RS mixed with both fines up to $20 \%$. Falling head permeability tests were performed on all remaining samples. The results of the tests are shown in Figure 5. The figure shows that the permeability of all three types of sands decreases with increasing fine contents. The rate of decrease in permeability is very weighty up until $20 \%$ fine content and then reduces significantly. Amongst the nonamended sands, LS had a maximum permeability value of $4.63 \times 10^{-3} \mathrm{~cm} / \mathrm{sec}$, whereas for CS and RS, the observed values were $2.14 \times 10^{-3} \mathrm{~cm} / \mathrm{sec}$ and $1.98 \times 10^{-3} \mathrm{~cm} / \mathrm{sec}$ respectively. These values seem to be related with their median grain size (D50). D50s for CS, LS and RS were 0.25, 0.87 and $0.22 \mathrm{~mm}$ respectively. In amended soils, the minimum permeability of $6.39 \times 10^{-6} \mathrm{~cm} / \mathrm{sec}$ was noted for RS mixed with 50\% PF.

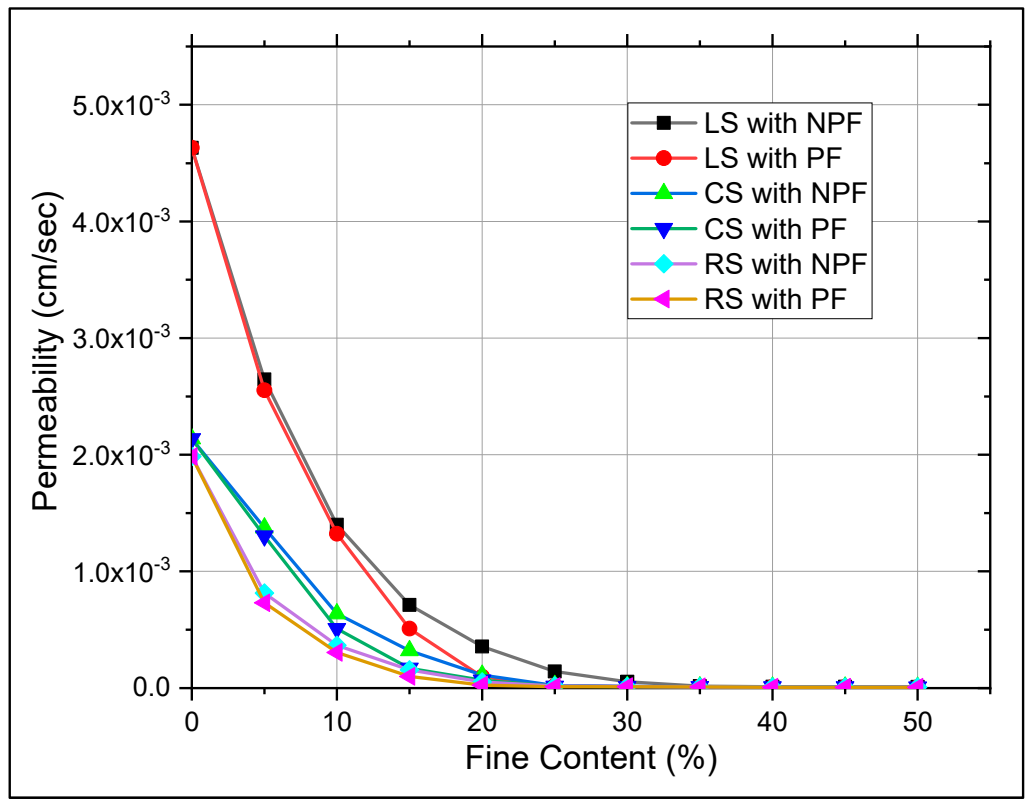

Figure 5. Variation in permeability with different fine contents. 


\subsection{The Development of Correlations}

Analyses were performed with the set of $\rho_{d}$ (dry density), $D_{10}, D_{30}, D_{50}, D_{60}, C_{u}$, and $C_{c}$ values to select the most suitable independent variables to develop correlations as D60 defines $60 \%$ of the soil particles are finer than this size, D30 defines $30 \%$ of the particles are finer than this size and D10 defines $10 \%$ of the particles are finer than this size. The results of the analysis of $\rho_{d}, D_{10}$ and $D_{50}$ on permeability are shown in Figures 6-8 respectively. The trend for permeability versus $\rho_{d}$ is a decreasing one, though the data is somewhat scattered. For both $\mathrm{D}_{10}$ and $\mathrm{D}_{50}$, the permeability increases with an increase in particle size.

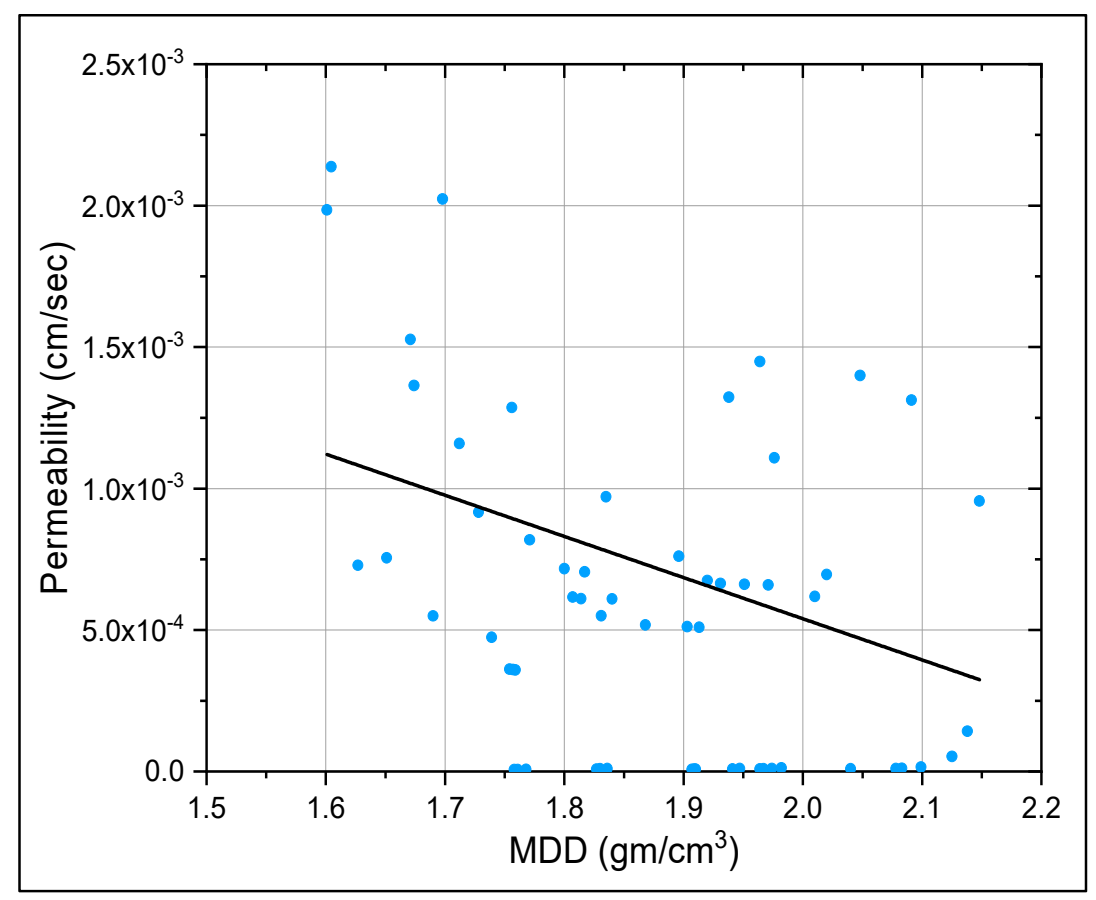

Figure 6. Permeability versus maximum dry density.

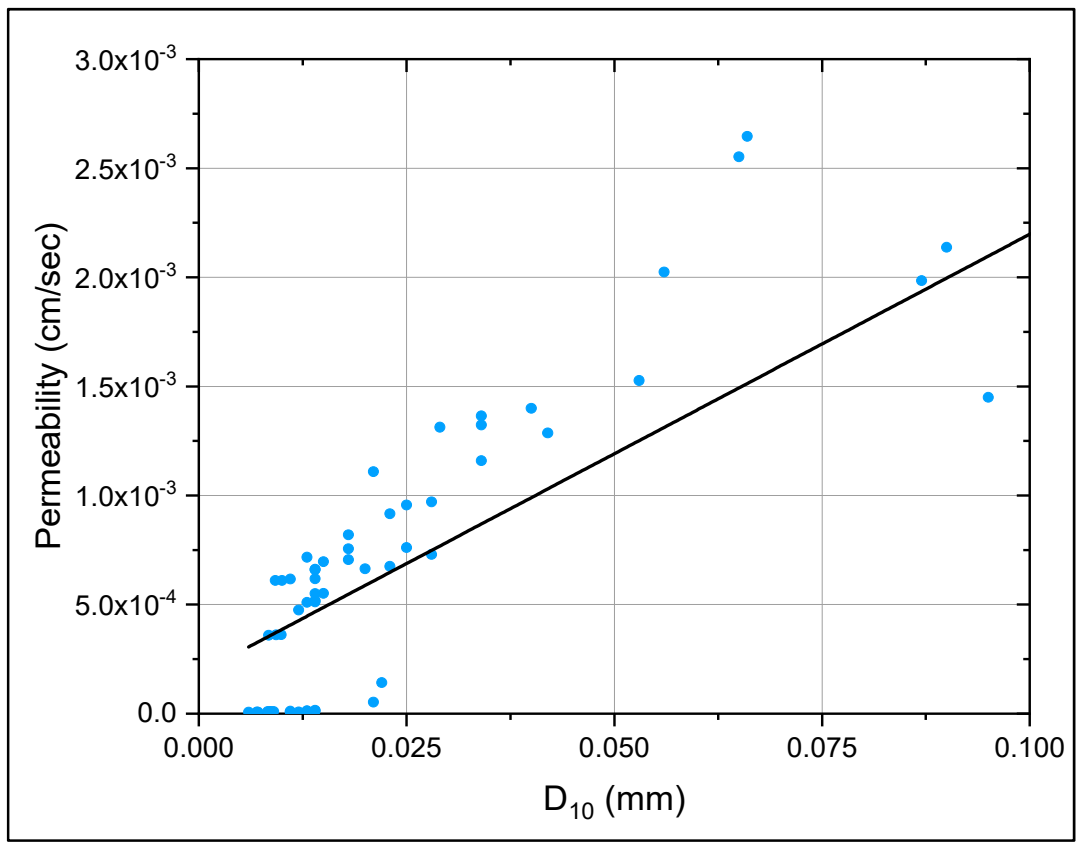

Figure 7. Permeability versus $\mathrm{D}_{10}$. 


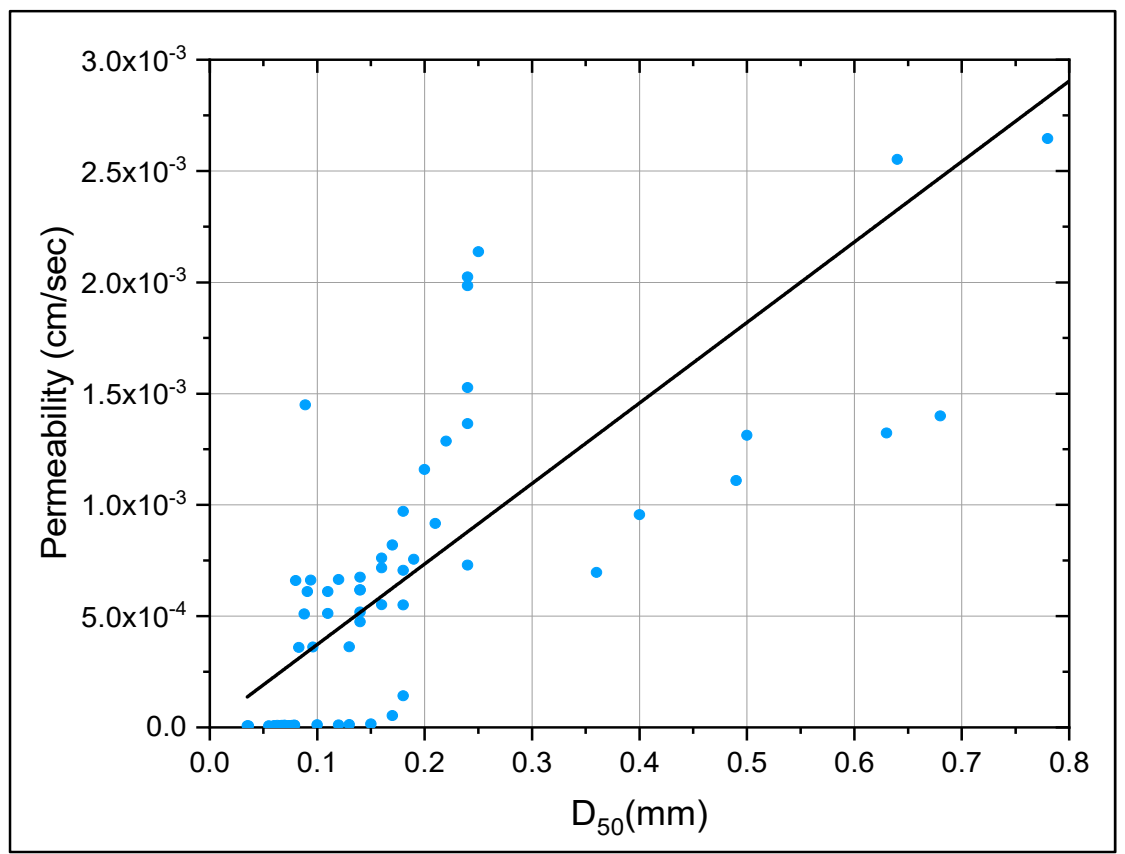

Figure 8. Permeability versus $D_{50}$.

Computer software "IBM SPSS Version 22" was used IBM SPSS Statistics (V22.0. 2016, IBM Corp, Armonk, NY, USA) for carrying out linear regression analysis to develop a correlation. A few trials were made and the best fit was obtained with $D_{10}, D_{50}$ and $\rho_{d}$. The value of coefficient of determination/R squared $\left(\mathrm{R}^{2}\right)$ was determined as 0.95 . The following equation was obtained.

$$
k=0.012 D_{10}+0.002 D_{50}-0.001 \gamma_{d}+0.002(\mathrm{~cm} / \mathrm{sec})
$$

Values predicted by the above equation were plotted against experimental values and the graph in Figure 9 was obtained. An 8.5\% residual standard error of estimate (RSE) was found.

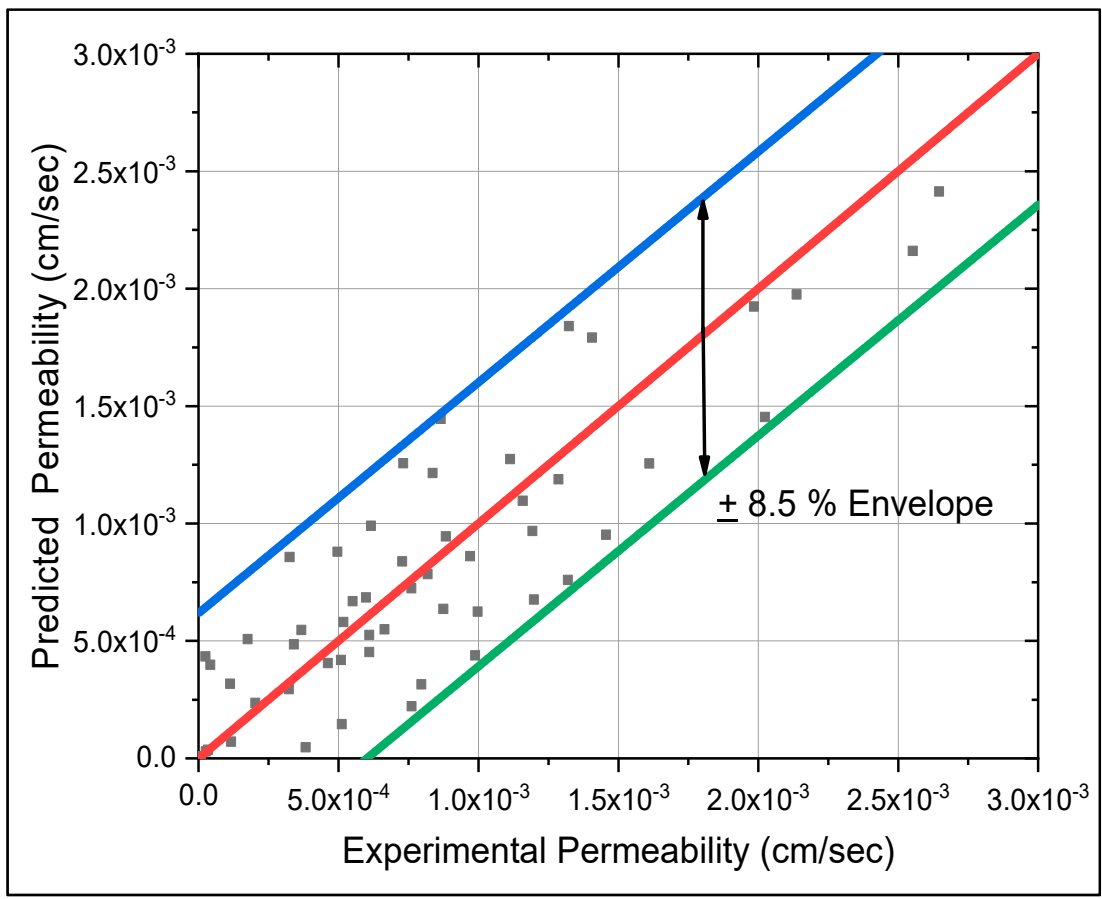

Figure 9. Predicted permeability versus experimental permeability. 


\subsection{Data Validation}

To investigate the validity of the equation, 52 data sets from the field were obtained from different areas of Pakistan. Nine data sets were from Lahore's Sewerage system (sample numbers: S1 to S9), 11 from the Taunsa Hydro Power Plant (sample numbers: S10 to S20), five from Defence Housing Authority (DHA) Lahore (sample numbers: S21 to S25) and 27 from Bhikki Power Plant Bhikki (sample numbers: S26 to S52). The characteristics of the data are listed in Table 2.

The data was tested with other familiar equations available in the literature; i.e., the Mujtaba equation [31], Kozeny-Carman equation [32-34] and Hazen equation [7,35]. The results are presented in Figure 10. The permeability values predicted by Mujtaba, Hazen and Kozeny-Carman equations do not really match with experimental values for hydraulic conductivity less than $3 \times 10^{-3} \mathrm{~cm} / \mathrm{sec}$. The equation proposed by present research (Equation (1)) also produced scattered data but that is only for hydraulic conductivity less than $1 \times 10^{-3} \mathrm{~cm} / \mathrm{sec}$. Interestingly, these predicted values (for hydraulic conductivity less than $1 \times 10^{-3} \mathrm{~cm} / \mathrm{sec}$ ) are greater than the experimental values. Thus, the predicted values are conservative and can be tolerated. The reason may be that the equation was developed for the mixes of local sands and fines. As mentioned earlier, it is somewhat difficult to predict the hydraulic conductivity of fine-grained soils. For hydraulic conductivity greater than $3 \times$ $10^{-3} \mathrm{~cm} / \mathrm{sec}$, all the equations yielded fairly good results. It is noted that the observed data best fits with the equation developed in the current research.

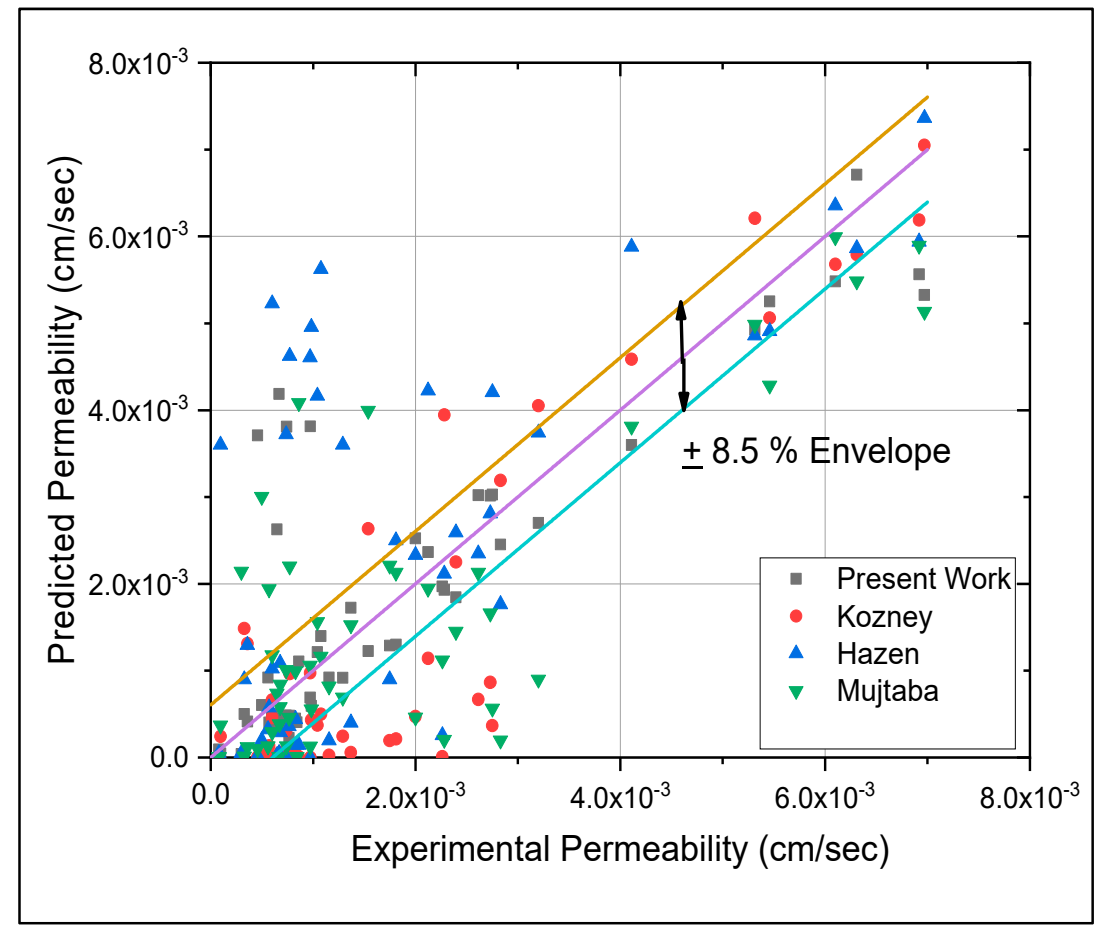

Figure 10. Comparison of equations. 
Table 2. Field permeability data for validation.

\begin{tabular}{|c|c|c|c|c|c|c|}
\hline \multirow[t]{2}{*}{ Sample No. } & Gravel & Sand & Fines & Soil Class. & $\gamma_{\mathrm{d}}$ & $\begin{array}{c}\text { Field } \\
\text { Permeability }\end{array}$ \\
\hline & $\%$ & $\%$ & $\%$ & USCS & $\mathrm{gm} / \mathrm{cm}^{3}$ & $\mathrm{~cm} / \mathrm{sec}$ \\
\hline S1 & 0 & 89 & 11 & SP-SM & 1.727 & $2.00 \times 10^{-3}$ \\
\hline S2 & 0 & 65 & 35 & SM & 1.688 & $2.83 \times 10^{-3}$ \\
\hline S3 & 0 & 91 & 9 & SP-SM & 1.748 & $7.37 \times 10^{-4}$ \\
\hline S4 & 0 & 81 & 19 & $\mathrm{SM}$ & 1.794 & $9.69 \times 10^{-5}$ \\
\hline S5 & 0 & 94 & 6 & SP-SM & 1.827 & $1.0 \times 10^{-3}$ \\
\hline S6 & 0 & 92 & 8 & SP-SM & 1.764 & $5.99 \times 10^{-4}$ \\
\hline S7 & 0 & 93 & 7 & SP-SM & 1.589 & $3.60 \times 10^{-4}$ \\
\hline S8 & 0 & 86 & 14 & $\mathrm{SM}$ & 1.836 & $1.29 \times 10^{-3}$ \\
\hline S9 & 0 & 90 & 10 & SP-SM & 1.735 & $1.08 \times 10^{-3}$ \\
\hline S10 & 0 & 57 & 43 & $\mathrm{SM}$ & 1.769 & $8.38 \times 10^{-5}$ \\
\hline S11 & 0 & 3 & 97 & ML & 1.782 & $7.42 \times 10^{-4}$ \\
\hline S12 & 0 & 2 & 98 & ML & 1.79 & $9.73 \times 10^{-4}$ \\
\hline S13 & 0 & 92 & 8 & SP-SM & 1.621 & $1.37 \times 10^{-3}$ \\
\hline S14 & 0 & 85 & 15 & $\mathrm{SM}$ & 1.6 & $5.59 \times 10^{-4}$ \\
\hline S15 & 0 & 85 & 15 & SM & 1.651 & $1.16 \times 10^{-3}$ \\
\hline S16 & 0 & 92 & 8 & SP-SM & 1464 & $2.12 \times 10^{-3}$ \\
\hline S17 & 0 & 97 & 3 & SP & 1.534 & $7.72 \times 10^{-4}$ \\
\hline S18 & 0 & 97 & 3 & $\mathrm{SP}$ & 1.596 & $1.81 \times 10^{-3}$ \\
\hline S19 & 0 & 91 & 9 & SP-SM & 1.526 & $1.54 \times 10^{-3}$ \\
\hline S20 & 0 & 88 & 12 & SP-SM & 1.527 & $1.75 \times 10^{-3}$ \\
\hline $\mathrm{S} 21$ & 0 & 91 & 9 & SP-SM & 1.675 & $2.61 \times 10^{-3}$ \\
\hline $\mathrm{S} 22$ & 0 & 85 & 15 & $\mathrm{SM}$ & 1.576 & $5.31 \times 10^{-3}$ \\
\hline $\mathrm{S} 23$ & 0 & 54 & 46 & SM & 1.775 & $6.92 \times 10^{-3}$ \\
\hline S24 & 3 & 11 & 86 & CL & 1.528 & $6.47 \times 10^{-4}$ \\
\hline $\mathrm{S} 25$ & 0 & 4 & 96 & CL & 1.625 & $4.58 \times 10^{-4}$ \\
\hline S26 & 0 & 93 & 7 & SP-SM & 1.499 & $2.39 \times 10^{-3}$ \\
\hline $\mathrm{S} 27$ & 2 & 87 & 11 & SP-SM & 1.479 & $5.71 \times 10^{-4}$ \\
\hline S28 & 1 & 95 & 4 & $\mathrm{SP}$ & 1.97 & $2.75 \times 10^{-3}$ \\
\hline S29 & 0 & 75 & 26 & SM & 1.719 & $5.46 \times 10^{-3}$ \\
\hline $\mathrm{S} 30$ & 0 & 49 & 41 & SM & 1.485 & $6.70 \times 10^{-4}$ \\
\hline S31 & 0 & 82 & 18 & SM & 1.79 & $5.00 \times 10^{-4}$ \\
\hline S32 & 0 & 73 & 27 & SM & 1.77 & $8.60 \times 10^{-4}$ \\
\hline S33 & 0 & 95 & 5 & SP-SM & 1.822 & $4.11 \times 10^{-3}$ \\
\hline S34 & 0 & 87 & 13 & SM & 1.777 & $3.20 \times 10^{-3}$ \\
\hline S35 & 1 & 94 & 5 & SP-SM & 1.698 & $9.720 \times 10^{-4}$ \\
\hline S36 & 0 & 80 & 20 & $\mathrm{SM}$ & 1.858 & $6.80 \times 10^{-4}$ \\
\hline S37 & 0 & 70 & 30 & SM & 1.82 & $8.43 \times 10^{-4}$ \\
\hline S38 & 0 & 83 & 17 & $\mathrm{SM}$ & 1.837 & $6.78 \times 10^{-4}$ \\
\hline S39 & 0 & 79 & 21 & SM & 1.988 & $5.99 \times 10^{-4}$ \\
\hline S40 & 0 & 59 & 41 & SM & 1.871 & $8.28 \times 10^{-4}$ \\
\hline S41 & 0 & 92 & 8 & SP-SM & 1.8 & $9.83 \times 10^{-4}$ \\
\hline $\mathrm{S} 42$ & 0 & 82 & 18 & SM & 1.821 & $2.99 \times 10^{-4}$ \\
\hline S43 & 0.5 & 84 & 15.5 & SM & 1.883 & $3.28 \times 10^{-4}$ \\
\hline S44 & 0.7 & 6.2 & 93.1 & CL-ML & 2.104 & $7.94 \times 10^{-05}$ \\
\hline S45 & 0 & 82.6 & 17.4 & $\mathrm{SM}$ & 1.901 & $2.28 \times 10^{-03}$ \\
\hline S46 & 0 & 85.3 & 14.7 & SM & 1.792 & $2.73 \times 10^{-03}$ \\
\hline S47 & 4.5 & 8.2 & 87.3 & CL & 2.056 & $6.68 \times 10^{-4}$ \\
\hline S48 & 0 & 86.8 & 13.2 & SM & 1.867 & $6.31 \times 10^{-3}$ \\
\hline S49 & 0 & 80 & 20 & $\mathrm{SM}$ & 1.849 & $6.97 \times 10^{-3}$ \\
\hline S50 & 0 & 79 & 21 & SM & 1.837 & $6.10 \times 10^{-3}$ \\
\hline S51 & 0 & 73.4 & 26.6 & SM & 1.816 & $7.66 \times 10^{-4}$ \\
\hline S52 & 0 & 73 & 27 & SM & 1.898 & $2.26 \times 10^{-3}$ \\
\hline
\end{tabular}




\section{Conclusions}

In this experimental work, the effect of adding fines to three different river sands on permeability (at maximum dry density and optimum moisture content) was studied. Moreover, an equation was developed to predict the permeability of sand and fine mixes. According to test observations and analyses, the outcomes can be summarized, as follows:

- The study of literature indicates that most equations developed for predicting the permeability are for granular soils with little effort being made for fine-grained soils. Analysis showed that the equation developed in this research is very much suitable for soils of local formations when fine content ranges from $0 \%$ to $50 \%$.

- The equation formulated with the experimental data was compared with three empirical equations and it was found that this equation predicted better with fine-grained soils (hydraulic conductivity value less than $3 \times 10^{-3} \mathrm{~cm} / \mathrm{sec}$ ) than the other three. The analysis also demonstrated that at lower ranges of fine contents, other equations perform well; however, as the percentages of fine content increases, their adaptability is questioned.

Author Contributions: T.A.K.; K.F.; M.M.; M.M.K.; S.A.R.S.; M.S.; M.A.A. and S.S.R. have equally contributed.

Funding: This research received no external funding.

Acknowledgments: The results of laboratory experiments presented in this paper have been performed at Geotechnical Engineering Laboratory of University of Engineering and Technology Lahore-Pakistan during the master thesis study of third author (M.M.). The technical assistance provided by Hassan Mujtaba of Department of Civil Engineering, University of Engineering and Technology Lahore-Pakistan during the thesis work and the technical guidance provided by the laboratory staff in performing experiments is highly acknowledged. The data of field permeability tests provided by M/s NESPAK, Pakistan (National Engineering Services Pakistan Pvt. Ltd.) is also acknowledged by the authors.

Conflicts of Interest: The authors declare no conflict of interest.

\section{References}

1. Sivapullaiah, P.; Sridharan, A.; Stalin, V. Hydraulic conductivity of bentonite-sand mixtures. Can. Geotech. J. 2011, 37, 406-413.

2. Tizpa, P.; Chenari, R.J.; Fard, M.K.; Machado, S.L. ANN prediction of some geotechnical properties of soil from their index parameters. Arab. J. Geosci. 2015, 8, 2911-2920.

3. Alhassan, M. Permeability of lateritic soil treated with lime and rice husk ash. Assumpt. Univ. J. Thail. 2008, 12, 115-120.

4. Roy, S.; Bhalla, S.K. Role of geotechnical properties of soil on civil engineering structures. Resour. Environ. 2017, 7, 103-109.

5. Elhakim, A.F. Estimation of soil permeability. Alex. Eng. J. 2016, 55, 2631-2638. [CrossRef]

6. Barzegari, G. Geotechnical evaluation of dam foundation with special reference to in situ permeability: A case study. Geotech. Geol. Eng. 2017, 35, 991-1011. [CrossRef]

7. Hazen, A. Discussion: Dams on sand foundations. Trans. Am. Soc. Civ. Eng. 1911, 73, 190-207.

8. Zunker, F. Das verhalten des bodens zum wasser. In Die Physikalische Beschaffenheit des Bodens; Springer: Berlin, Germany, 1930; pp. 66-220.

9. Carman, P.C. Fluid flow through granular beds. Trans. Inst. Chem. Eng. 1937, 15, 150-166. [CrossRef]

10. Burmister, D. Principles of permeability testing of soils. In Symposium on permeability of soils; ASTM International: West Conshohocken, PA, USA, 1955; pp. 3-26.

11. Michaels, A.S.; Lin, C. Permeability of kaolinite. Ind. Eng. Chem. 1954, 46, 1239-1246. [CrossRef]

12. Olsen, H.W. Hydraulic flow through saturated clays. Clays Clay Miner. 1960, 9, 131-161.

13. Mitchell, J.K.; Hooper, D.R.; Campenella, R.G. Permeability of compacted clay. J. Soil Mech. Found. Division 1965, 91, 41-66.

14. Wang, M.; Huang, C. Soil compaction and permeability prediction models. J. Environ. Eng. 1984, 110, 1063-1083. [CrossRef] 
15. Alyamani, M.S.; Şen, Z. Determination of hydraulic conductivity from complete grain-size distribution curves. Groundw. 1993, 31, 551-555. [CrossRef]

16. Koltermann, C.E.; Gorelick, S.M. Fractional packing model for hydraulic conductivity derived from sediment mixtures. Water Resour. Res. 1995, 31, 3283-3297. [CrossRef]

17. D'Andrea, R.; Boadu, F.K. Hydraulic Conductivity of Soils from Grain-Size Distribution: New Models. J. Geotech. Geoenviron. Eng. 2001, 127, 899-900. [CrossRef]

18. Chapuis, R.P. Predicting the saturated hydraulic conductivity of sand and gravel using effective diameter and void ratio. Can. Geotech. J. 2004, 41, 787-795. [CrossRef]

19. Sinha, S.K.; Wang, M.C. Artificial neural network prediction models for soil compaction and permeability. Geotech. Geol. Eng. 2008, 26, 47-64. [CrossRef]

20. Côté, J.; Fillion, M.-H.; Konrad, J.-M. Estimating hydraulic and thermal conductivities of crushed granite using porosity and equivalent particle size. J. Geotech. Geoenviron. Eng. 2011, 137, 834-842. [CrossRef]

21. Cabalar, A.F.; Akbulut, N. Evaluation of actual and estimated hydraulic conductivity of sands with different gradation and shape. SpringerPlus 2016, 5, 820. [CrossRef]

22. van Ginkel, M.; Olsthoorn, T.N. Distribution of grain size and resulting hydraulic conductivity in land reclamations constructed by bottom dumping, rainbowing and pipeline discharge. Water Res. Manag. 2019, 33, 993-1012. [CrossRef]

23. Carrier, W.D., III. Goodbye, hazen; hello, kozeny-carman. J. Geotech. Geoenviron. Eng. 2003, 129, $1054-1056$. [CrossRef]

24. Göktepe, A.B.; Sezer, A. Effect of particle shape on density and permeability of sands. Proc. the Inst. Civ. Eng.-Geotech. Eng. 2010, 163, 307-320. [CrossRef]

25. Jabro, J. Estimation of saturated hydraulic conductivity of soils from particle size distribution and bulk density data. Trans. ASAE 1992, 35, 557-560. [CrossRef]

26. Holtz, R.D.; Kovacs, W.; Sheahan, T. An Introduction to Geotechnical Engineering, 2nd. 2011; Pearson plc: London, UK, 1981.

27. DeGroot, D.; Ostendorf, D.; Judge, A. In situ measurement of hydraulic conductivity of saturated soils. Geotech. Eng. J. SEAGS AGSSEA 2012, 43, 63-72.

28. Kalkan, E.; Akbulut, S. The positive effects of silica fume on the permeability, swelling pressure and compressive strength of natural clay liners. Eng. Geol. 2004, 73, 145-156. [CrossRef]

29. Ameta, N.; Wayal, A.S. Effect of bentonite on permeability of dune sand. Electron. J. Geotech. Eng. 2008, 13, $1-7$.

30. Muhammad, M. Experimental Study on Permeability Characteristics of Sand Mixed with Fine Grained Soils. MS Thesis, University of Engineering \& Technology, Lahore, Pakistan, 2016.

31. Mujtaba, H. Development of correlations between various geotechnical parameters for granular soils in Punjab. Ph.D Thesis, University of Engineering and Technology, Lahore, Pakistan, 2015.

32. Kozeny, J. Uber Kapillare Leitung Des Wassers in Boden. R. Acad. Sci. 1927, 73, 271-306.

33. Carman, P.C. The determination of the specific surface of powders. I. J. Soc. Chem. Ind. 1938, 57, 225.

34. Carman, P.C. Flow of gases through porous media; Butterworths Scientific Publications: London, UK, 1956.

35. Hazen, A. Some physical properties of sands and gravels, with special reference to their use in filtration, 24th annual report; Massachusetts State Board of Health: Boston, MA, USA, 1983; pp. 539-556.

(C) 2019 by the authors. Licensee MDPI, Basel, Switzerland. This article is an open access article distributed under the terms and conditions of the Creative Commons Attribution (CC BY) license (http://creativecommons.org/licenses/by/4.0/). 